\title{
Developing a Test Based on the 21st Century Skills
}

\author{
Wahyudi $^{1,2^{*}}$, Badrun Kartowagiran ${ }^{1}$, Haryanto ${ }^{3}$, Mobinta Kusuma ${ }^{1}$, Purwoko \\ Haryadi Santoso ${ }^{1,4}$, Syamsul Bahri ${ }^{1,5}$ \\ ${ }^{1}$ Department of Educational Research and Evaluation, Postgraduate Program, Universitas Negeri Yogyakarta, \\ Indonesia \\ ${ }^{2}$ SMKN 1 Budong-Budong, Central Mamuju, Sulawesi Barat, Indonesia \\ ${ }^{3}$ Department of Electrical Engineering, Education, Faculty of Engineering, Universitas Negeri Yogyakarta, Indonesia \\ ${ }^{4}$ Department of Physics Education, Faculty of Teacher Training and Education, Universitas Sulawesi Barat, \\ Indonesia \\ ${ }^{5}$ Department of Physics Education, Faculty of Teacher Training dan Education, Universitas Musamus, Indonesia \\ *Corresponding author.Email: wahyudi.2021@student.uny.ac.id
}

\begin{abstract}
Teaching in Industrial Revolution 4.0 era addresses to create the 21 st century skills, so there is a need to develop an instrument for assessing these skills. This research aims to develop a test of critical and creative thinking skill which fulfils the validity and reliability criteria. These skills are the dimensions of the 21 st century skills. This research was conducted at one of the schools in South Sulawesi with the respondents consisting of 32 grade XI science students. Test form is an essay with the combination of some materials in physics. The development followed the following steps: (1) formulation of conceptual and operational definition, (2) designing the instrument, (3) expert justification, (4) trial, (5) analysis, (6) revision of instrument, dan (7) final instrument draft. The research results show that critical thinking test has fulfilled the validity and reliability criteria with three items of interpretation, three items of analysis, three items of inference and one item of inference. The reliability of the instrument is 0.82 on the first testing and 0.68 on the second testing. The creative thinking test also has fulfilled the validity and reliability criteria with three items of fluency, two items of flexibility, four items of originality, three items of elaboration and three items of evalution. The reliability of the instrument is 0.94 on the first testing and 0.74 on the second testing. These results show that the instrument of critical thinking and creative thinking have strong reliability and meet the requirements for proper instrument.
\end{abstract}

Keywords: Creative thinking, critical thinking, the 21st century skills, reliability.

\section{INTRODUCTION}

The development of science and technology is fast. This disruption requires fast change also in the learning area and it means that they require an adaptable approach. Indonesia is one of the G-20 members, which is expected to have the ability for competing in Industrial Revolution 4.0. as Industrial Revolution 4.0 refers to the industrial system that is based on digitalization, smart machine, and the Internet of things (IoT). In other words, technology of factories in industry mobilized by robots uses cyber-physical system. This is a huge revolution and Indonesia should change its industrial system, from the manual system to the digital system

The competition in the 21 st century is inversely proportional to the facts about Indonesia's position in Program for International Student Assessment (PISA) and Trends in International Mathematical and Science Studies (TIMSS). The results in 2015 PISA show Indonesia was ranked 64 out of 74 countries that are members of the Organization for Economic Cooperation and Development (OECD) with a score of 406 for scientific literacy. This score is still very low when compared to the average score for all OECD member 
countries, which is 493. Meanwhile, Indonesia's position in the TIMSS shows that students' science score was ranked 45 out of 48 countries with a score of 397. This means that there are still many things that need to be evaluated from the education system in Indonesia as a future projection [1].

As a solution to these problems, students should be taught to develop their thinking skills, so they can think complexly and have high order thinking skills (HOTS). Complex thinking described by skill that includes critical thinking skills, creative thinking, problem solving, and drawing conclusions [2]. Meanwhile, HOTS based on the revision of Bloom's Taxonomy by Anderson and Krathwohl includes the ability to analyze, evaluate, and create. Combination of complex thinking and HOTS become the 21st century skills [3]

The 21 st century skills are the skills that today's students should have. To discover the description of these skills requires a valid instrument so that the results can be trusted, because good measurement results are determined by good measuring instruments as well. Therefore, the instrument is very important to be developed [4].

The 21st century skills that should be possessed. They are as follows. (1) Ways of thinking, which are some thinking skills that must be mastered by students to face the world of the 21 st century. These thinking abilities include: creative and critical thinking, problem solving, decision making, and learning. (2) Ways of working, which are the skills how they should work with the global and digital world. Some skills that must be mastered by students are communication and collaboration. The $21 \mathrm{st}$ century generation should communicate well, using various methods and communication strategies. In addition, they should collaborate and work with individuals as well as communities and networks. This communication and cooperation network utilizes various ways, methods, ICT-based strategy, and how one should be able to work together with different skills. (3) Tools for working, which someone must have and master in order to be able to work. The mastery of information and communication technology (ICT) and information literacy is a must. Without ICT and information sources based on all sources, it will be difficult for someone to develop their career. (4) The skill for living in the world, which is the ability to live life in the $21 \mathrm{st}$ century, namely: citizenship, life and career, and personal and social responsibility [5][6].

Meanwhile, in the other expert classify the 21st century skills as follows. (1) In terms of skills in learning and innovation, the 21 st century skills include critical thinking, problem solving, communication, collaboration, creativity, and innovation skills. (2) In terms of literacy skills, they include information literacy, media literacy, and ICT literacy. (3) In terms of career and life skills, they include flexibility, adaptation, initiation, self-direction, social interaction, cross culture, leadership, and responsibility [7]

Finally, In Curriculum 2013, the 21st century skills are constructed simply with four dimensions (4C), namely critical thinking, creative thinking, collaboration, and communication [8]. Hence, the researcher in developing a test instrument focused on the critical thinking and creative thinking dimension, because these domains can be developed by using an essay test.

In addition to strengthening the learning process, another aspect that needs to be considered is an assessment of the thinking skills possessed by students [9]. Assessment is required for assessing each learning implementation so that the progress of the intervention process given to students can be understood. It is expected to provide solutions to problems in learning. However, one of the problems that appears in school is lack of teachers in schools for developing instruments for these skills. For this reason, the researchers developed an instrument based on the 21 st century skills. This instrument is important to develop since the measurement results are strongly affected by the quality of the measuring instrument used, and the quality of the measuring instrument is determined by the validity and reliability of the instrument, obtained through several validation steps and empirical tests in a limited group.

\section{RESEARCH METHOD}

\subsection{Type of Reseacrh}

This research is developmental research that used the test instrument development model suggested by Gable, Djaali and Mulyono, which is modified by combining several other expert opinions. The steps for developing a test instrument in general are (1) formulating conceptual and operational definitions, (2) designing instruments, (3) reviewing statements, (4) testing, (5) analysing, (6) revising instruments, and (7) arranging instrument to be the final instrument [10][11].

\subsection{Variable Oparational Definition}

To avoid misperceptions, the researchers defined operational research variables as follows: (1) the 21st century skills are the skills expected in Curriculum 2013 with indicators taken being critical thinking and creative thinking skills; (2) the critical thinking skill indicator used in this study is guided by the critical thinking skill indicator proposed by Facione, Marzano and Wade, which had been modified and adapted to the characteristics of the research material, with the indicators including interpretation, analysis, inference, evaluation, and explanation [12][13][14]; (3) the indicator of creative thinking skill used in this study is guided by the indicator of creative thinking skill 
proposed by Weiping $\mathrm{Hu}$ and Munandar, which had been modified and adapted to the characteristics of the research material and these indicators are fluency thinking, flexible thinking, original thinking, elaboration thinking, and evaluative thinking[15][16]; (4) the instrument developed is a test; (5) the developed test is considered valid and reliable if the results of the expert test and empirical test fulfil the valid and reliable criteria.

\subsection{Procedure of Development}

The stages of developing the $21^{\text {st }}$ century skill instruments are described as follows:

\subsubsection{Formulating conceptual and operational definitions}

\subsubsection{Designing instrument}

The purpose of this design stage was to prepare the topic of the instrument that would be constructed. The topics chosen were Newton's laws; work and energy; and momentum, impulse and collision. The format used was a test instrument in the form of an essay. The researcher also made a grid based on indicators from conceptual and operational definitions of critical and creative thinking skills as the basis for compiling the test. This designed test was referred to as draft I.

\subsubsection{Statement review}

The statement review was conducted by two experts. The experts who checked give suggestions and opinions related to draft I, which was analyzed and revised so that it became draft II.

\subsubsection{Testing}

At this stage, the results of statement review were tested restrictedly. The testing was conducted at one of the schools on South Sulawesi, involving grade XI science students.

\subsubsection{Analysis}

Based on the data from the testing results, further analysis was conducted to determine the validity of the item and the reliability of the instrument. The testing results of the instrument were referred to as draft II. The draft was analyzed and revised again to produce draft III. Draft III was an instrument that was valid and had strong reliability.

\subsubsection{Revising Instrument}

The revision of the instrument was conducted after going through the analysis. There were items that needed to be corrected in the language aspect. The items that had been revised were rearranged and their validity and reliability were recalculated.

\subsubsection{Revising The Instrument Into The Final Instrument}

\subsection{Instrument of Development}

The descriptions of the instruments used in this study are as follows:

\subsubsection{Expert validation sheet}

This instrument is used to validate the 21 st century skill instrument. The results of the validation conducted by the experts are in the form of suggestions and opinions of the validators that were used to revise the instrument. In addition, the validator filled in a column containing general conclusions about the content validity.

\subsubsection{The 21 st century skill instrument}

The 21st century skill instrument is a test which, after theoretical and empirical validation, met the validity and reliability criteria.

\section{FINDINGS AND DISCUSSION}

The findings and discussion show the step-by-step development. This description is used to show how the the instrument had gone through changes, because it had been revised in each step.

\subsection{Designing Instrument}

From various basic competencies in the syllabus, a test of critical and creative thinking skills was designed on physics subject as many as 16 and 21 test items, respectively. The design of the instrument for creative thinking skills test is shown in Table 2.

The test instrument was validated by different experts and analyzed using Gregory table on each test item [17]. Based on the assessment results from two experts, the reliability coefficient of the essay test on critical thinking skills was 0.69 and that on creative thinking skills was 0.57. After the instrument was revised based on expert judgment, all aspects of expert assessment of the $21^{\text {st }}$ century skill instrument were eligible.

Several suggestions from experts are required to be considered in revision: (1) pictures and descriptions on items needed clarification, (2) there needed to be the use of standard and clear item statements, (3) attention should be paid to typing errors, and (4) items that were not relevant to what to measure should be eliminated. 
Table 1. The design of critical thinking skill items

\begin{tabular}{|l|l|}
\hline Indicator of critical thinking skill & Total \\
\hline Interpretation & 4 items \\
\hline Analysis & 4 items \\
\hline Inference & 4 items \\
\hline Explanation & 4 items \\
\hline Total & 16 items \\
\hline
\end{tabular}

Table 2. The total of creative thinking skill item

\begin{tabular}{|l|l|}
\hline Indicator of critical thinking skill & Total \\
\hline Fluency & 4 items \\
\hline Flexibility & 4 items \\
\hline Originality & 4 items \\
\hline Elaboration & 4 items \\
\hline Evaluation & 5 Items \\
\hline Total & 21 items \\
\hline
\end{tabular}

\subsection{Analysis of Data}

After the test, the data analysis was conducted for each instrument of critical and creative thinking skills. The results of data analysis showed the number of valid and invalid items. The analysis used several descriptive statistics, that are elaborated as follows.

\subsubsection{Analysis of Items}

From the 11 critical thinking skills test items that were analyzed, the number of valid items was 10 items, while all items from the creative thinking skills test were in the valid category. The second testing was conducted on the same subject which used valid items as the results of the first testing. The results showed that all tested items were in the valid category for each critical and creative thinking skill test. The formula to find out the valid and invalid test items was the product moment formula.

\subsubsection{Reliability of Instrument}

The result of the first testing showed that the reliability of the test of the critical thinking skill was 0.82 , and that of the creative thinking skill was 0.94 . The second testing showed that the reliability of test of critical thinking skill was 0.68 , and that of the creative thinking skill was 0.74 . The formula used was Alpha Cronbach. These showed that the critical and creative thinking skills had high reliability for the first and the second tests.

Table 3. The Total of critical thinking skill items

\subsection{Revising the Instrument into the Final Instrument}

The final instrument was the accumulation of expert reviews and testing results. It was referred to as draft III. The number of valid final items for the critical thinking skills test is shown in Table 3 .

Interpretation indicators were presented in the graphical form. The graphs were interpreted by students so that the aspects of the ability to interpret could be measured properly through these questions. In addition, the statement of test items was made contextually with daily life so that students could make a reason about the implications in the real world. The indicators of analysis were made in the form of problems related to motion, work, and energy. Each statement content was designed in such a way that it was contextual in daily life, for example using the motion of a ball in a joy ride in the surrounding area, a car that was in a tilted position and a bucket as a load connected to a rope on a pulley.

Furthermore, the test was designed in such a way as to make students curious and think imaginatively so that they could solve the problems. The explanation indicator was designed as a problem about the motion of the trolley which students were expected to explain well what the problem was. This was important for students to know the skill to view a problem was more complex and to make explanation well every aspect of the item. The output was expected that students could solve problems and provide inferences when given premises relating to physics. The valid and reliable creative thinking skill test is shown in Table 4.

\begin{tabular}{|l|l|}
\hline Indicator of critical thinking skill & Total \\
\hline Interpretation & 3 items \\
\hline Analysis & 3 items \\
\hline Inference & 3 items \\
\hline Explanation & 1 items \\
\hline Total & 10 items \\
\hline
\end{tabular}


Table 4. The Total of Creative Thinking Skill Item

\begin{tabular}{|l|c|}
\hline Indicator of critical thinking skill & Total \\
\hline Fluency & 3 items \\
\hline Flexibility & 2 items \\
\hline Originality & 4 items \\
\hline Elaboration & 3 items \\
\hline Evaluation & 3 Items \\
\hline Total & 15 items \\
\hline
\end{tabular}

Fluency indicators were designed by providing problems in the context of daily life. It was expected that students would be given a stimulus to provide alternative solutions to the problem spontaneously, hence fostering creativity in students. Furthermore, flexibility was designed for a test item that had many ways to solve so that students were not fixated on one way only and could compare with other ways. This was important in training students to answer test items with various alternatives.

Originality indicators were designed test items that were completed without a formula. These items could test the authenticity of the student's answers, because the calculation test without formulas is unusual in physics. The elaboration indicator was designed by providing problems and students were asked to provide many solutions to these problems. The items given were not in the form of mathematical calculations but in the form of physics concepts related to daily life. This point was totally supportive of how the creative minds of students provided solutions to the problems given. Evaluation indicators were designed with items that students could be tested on how to judge whether premise was right or wrong. This was given in order to support student to determine the correct answer to the problems given and also to grow their literacy skills.

\subsection{Discussion}

The results of the design (draft I) were reviewed by two different experts. This was done to see the consistency of the two experts in assessing the relevance between the items and the indicators to be measured. Another aspect that was assessed was the language and content used in each test item. The assessment criteria used four criteria, namely a score of 4 if the instrument items were totally appropriate (totally relevant) to the indicator; score of 3 if the item of the instrument was appropriate (relevant) to the indicator; score of 2 if the item of the instrument was not appropriate (irrelevant) to the indicator; and a score of 1 if the instrument item was not totally appropriate (totally irrelevant) to the indicator. The results of expert validation were analyzed using the Gregory table and showed that 11 of the 16 items of the critical thinking skills test had a strong relevance between the indicators and the items, and 15 of the 21 items of the creative thinking skills test also had a strong relevance, with a note that three items on fluency indicators were revised by clarifying item statements. The item statement that was not clear was the absence of a minimum standard of how many answers were required for each item, which was used to assess the students' answers. The reliability of the critical thinking skills test was 0.69 and that of the creative thinking skills test was 0.57 . The result of the improvement based on expert justification was referred to as draft II.

Draft II was used for testing in the school. The testing was conducted at one of the schools in South Sulawesi involving 32 students as respondents with the purpose of obtaining empirical validity and reliability of the developed instrument. The test results were analyzed using the product moment formula to determine the validity and Cronbach's alpha to determine the reliability of the instrument [18][19]. The result was a critical thinking skill test with 10 valid items and one invalid item with a reliability coefficient of 0.82 , while all items on the creative thinking skills test were in the valid category with the reliability coefficient of 0.94 . The second stage of the testing was conducted after the first stage of the testing to look the consistency of the measurement results on the same object by taking valid items in the previous test. Draft III was the final draft of developing the $21 \mathrm{st}$ century skill instruments and became an items bank that could be used to measure critical thinking skills and creative thinking skills of participants validly and reliably in school.

Based on theory, the instrument can be used in general user when the instrument has valid and reliability criteria and this research has showed that critical thinking and creative thinking instrument has fulfilled these criteria, hence the instrument can be used in general user for testing student in physics subject.

\section{CONCLUSION}

Based on the results of research, the following conclusions can be drawn. The developed critical thinking skill instrument meets the validity and reliability criteria after content validity by experts and empirical testing had been conducted. The creative thinking skill instrument meets the validity and reliability criteria also after content validation by experts and empirical testing had been conducted. 


\section{ACKNOWLEDGMENTS}

This research was supported by a physics teacher as advisor and students as respondents for testing of instrument for empirical test.

\section{REFERENCES}

[1] I. Ahmad, Pendidikan tinggi " 4.0 " yang mampu meningkatkan daya saing bangsa. Direktur Jenderal Pembelajaran dan Kemahasiswaan, Kementerian Riset, Teknologi, Dan Pendidikan Tinggi, 2018.

[2] M. Tawil, (2013). Berpikir kompleks dan implementasinya dalam pembelajaran IPA, Badan Penerbit UNM, 2013.

[3] J. Anderson, Assesing the 21st century skills, National Academic Press, 2011.

[4] Nurdin, Evaluasi pendidikan, Bumi Askara, 2007.

[5] P. Griffin, Assesment and teaching of the 21st century skills, Springer Science Business Media, 2012.

[6] Tim BSNP, Paradigma pendidikan nasional abad XXI. Buletin BSNP, Vol. VIII/ No.1, 2013.

[7] B. Trilling, C. Fadel, The 21st century skills: learning for life in our times. John Wiley \& Sons, Inc, 2009.

[8] S. Resti, R. Frasandy, Keterampilan 4C abad 21 dalam pembelajaran pendidikan dasar, 2018.

[9] R. Slavin, Educational psychology teory and practice (8th ed.), Pearson 2006.

[10] Djaali, P. Mulyono, Pengukuran dalam bidang pendidikan, Grasindo, 2008.

[11] R.K. Gable, Instrument development in the affective domain, Springer, 2013.

[12] S.M. Brookhart, How to assesing high order thinking skills, Association for Supervision and Curriculum Development, 2010.

[13] R. Marzano, Dimension of thinking: A frame for curriculum and instruction. Association for Supervision and Curriculum Development, 1993.

[14] C. Wade, Using writing to develop and assess critical thinking, Teaching of Psychology, 22(1), pp. 24-28, 1995, https://doi.org/10.1207/s15328023top2201_8

[15] W. Hu, P. Adey, A scientific creativity test for secondary school students. International Journal of Science Education, 24(4), pp. 389-403. 2002, https://doi.org/10.1080/09500690110098912
[16] U. Munandar, Pengembangan kreativitas anak berbakat, Rineka Cipta, 2014.

[17] R. Gregory, Psychological testing: History, principles, and applications. Pearson, 2017.

[18] S. Suryabrata, Pengembangan alat ukur psikologis. Andi Offet, 2002.

[19] S. Arikunto, Dasar-dasar evaluasi pendidikan, Bumi Aksara, 2013. 